\title{
STABILITY OBSERVATIONS AND SURFACE ANALYSIS OF AIR FIRED NICKEL THICK FILM CONDUCTORS
}

\author{
R.B. PRANCHOV ${ }^{\dagger}$ and D.S. CAMPBELL $\ddagger$ \\ (Received November 8, 1982; in final form February 12, 1984)
}

\begin{abstract}
The results from an investigation of the properties of air fired Nickel thick film produced with conductive paste ESL 2554 on $96 \% \mathrm{Al}_{2} \mathrm{O}_{3}$ substrates are described. The analysis of the possible causes of instability of this thick film material has been done using the methods of surface analysis. The picture of the film surface structure obtained as a result of surface analysis shows a non-isotropic distribution of the metal and glass phase. For a firing peak temperature of $650^{\circ} \mathrm{C}$ there is little nickel present at the film surface, and this could be the main cause of the high instability and low adhesion observed. To obtain a stable film the maximum firing peak temperature has been established at $580^{\circ} \mathrm{C}$. This has been confirmed by comparing the surface analysis results from films prepared at $650^{\circ} \mathrm{C}$ and $580^{\circ} \mathrm{C}$ peak temperatures.

The surface analysis of the substrate shows the presence of Silicon which may be considered as another possible cause of film instability.
\end{abstract}

\section{INTRODUCTION}

The use of cheap thick films would increase the application of thick-film circuits. Air fireable ruthenium based thick-film resistors are obtainable with excellent properties and at a reasonable price. However conductive thick-films based on silver, gold, palladium and platinum which have suitable properties are relatively expensive. Because of this, efforts have been directed towards the creation of new air fireable low cost conductors, and new air fireable conductive pastes have appeared on the market. This paper is concerned with one of these new air fireable conductive thick films.

The present authors have investigated a nickel air fireable conductive paste - ESL 2554. The data about this paste is available in Bulletin 3281 of ESL Inc., ${ }^{1}$ and the results of investigations of their properties have been presented by Stein et al. ${ }^{2}$ Nickel paste (ESL 2554) is appropriate for printing on soda-lime glass, porcelain enamelled steel, $96 \% \mathrm{Al}_{2} \mathrm{O}_{3}$ and silicon wafers, and using a range of peak firing temperature from $580^{\circ} \mathrm{C}$ to $930^{\circ} \mathrm{C}$. The sheet resistance of the Nickel film decreases from 70 to $35 \mathrm{~m} \Omega / \mathrm{sq}$. as the peak firing temperature is increased from $580^{\circ} \mathrm{C}$ to $930^{\circ} \mathrm{C}$.

\section{EXPERIMENTAL ARRANGEMENTS}

A thick film resistive circuit had been designed in order to investigate the behaviour of noise for different resistor lengths and different overlaps between the resistive and conductive thick films (Figure 1). 96\% Alumina substrates and resistive pastes from ESL 3100 series were used together with Nickel conductors. The firing conditions for the Nickel were chosen to have a peak temperature of $775^{\circ} \mathrm{C}$ and a

\footnotetext{
${ }^{\dagger}$ On leave of absence at Loughborough University of Technology from the:- Telecommunication Department, Higher Institute of Mechanical and Electrical Engineering, 1156 Sofia, BULGARIA.

${ }^{\ddagger}$ Electronic. Elec. Eng. Dept, Loughborough University of Technology, Loughborough, Leics, U.K.
} 


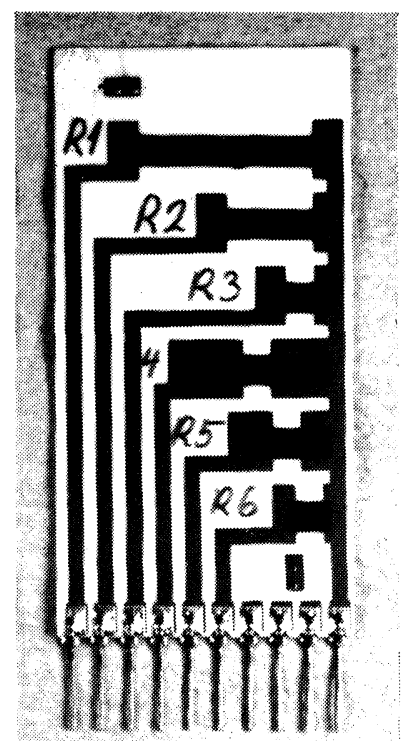

FIGURE 1 Layout diagram (Substrate size 2" $\times 1$ 1").

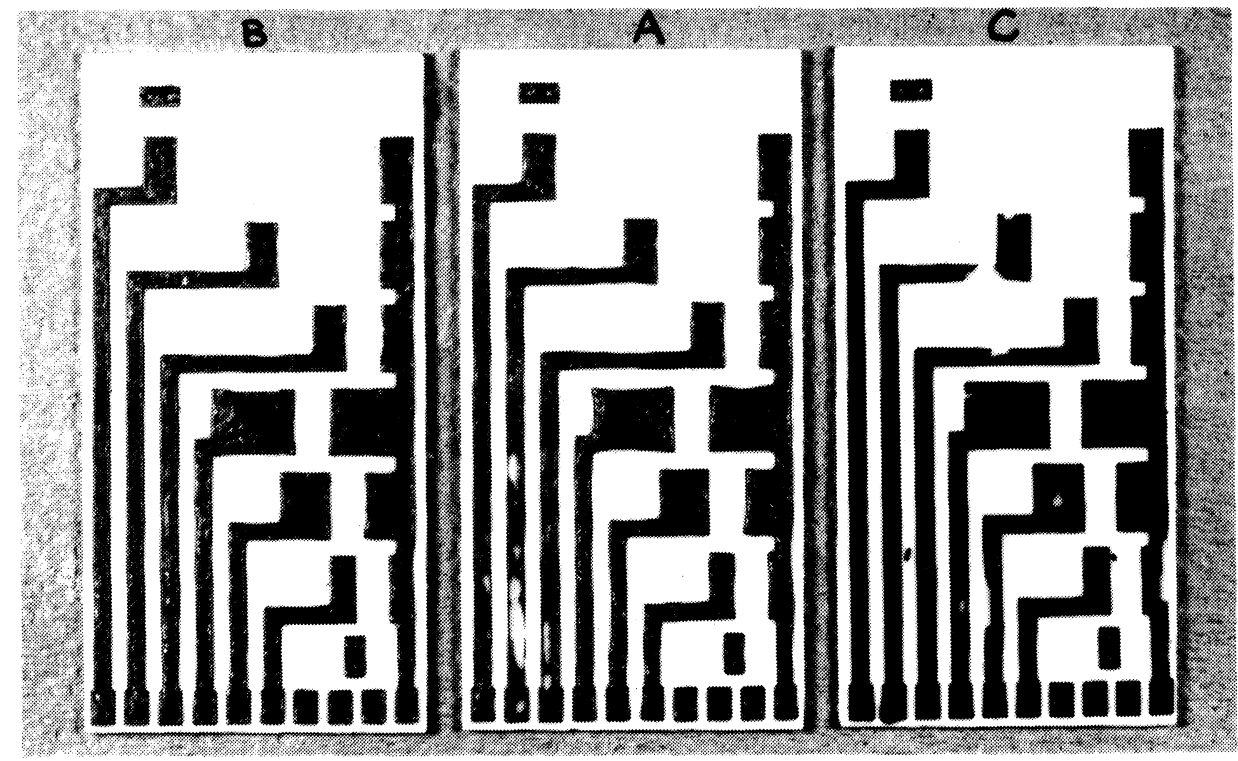

FIGURE 2 Ni thick film fired at firing temperatures of:- A) $\left.775^{\circ} \mathrm{C}, \mathrm{B}\right) 750^{\circ} \mathrm{C}, \mathrm{C}$ ) $700^{\circ} \mathrm{C}$. (Substrate size $2 " \times 1 ")$.

belt furnace firing cycle of $45 \mathrm{~min}$ with $10 \mathrm{~min}$ at peak temperature, as indicated in reference 2. It was discovered that the peak temperature of $775^{\circ} \mathrm{C}$ was too high for the air fireable Nickel paste. It was not possible to obtain a smooth Nickel thick film at all, as can be seen in Figure 2A. Because of the published dependences of the resistivity on peak temperature ${ }^{1,2}$ further firing conditions were therefore used 
TABLE I

Firing conditions

\begin{tabular}{llll}
\hline $\begin{array}{l}\text { Firing } \\
\text { conditions }\end{array}$ & Peak temperature & $\begin{array}{l}\text { Time at peak } \\
\text { temperatures }\end{array}$ & $\begin{array}{l}\text { Total firing } \\
\text { cycle }\end{array}$ \\
\hline 1 & $775^{\circ} \mathrm{C}$ & $10 \mathrm{~min}$ & $45 \mathrm{~min}$ \\
2 & $750^{\circ} \mathrm{C}$ & $10 \mathrm{~min}$ & $45 \mathrm{~min}$ \\
3 & $710^{\circ} \mathrm{C}$ & $10 \mathrm{~min}$ & $45 \mathrm{~min}$ \\
4 & $650^{\circ} \mathrm{C}$ & $10 \mathrm{~min}$ & $45 \mathrm{~min}$ \\
\hline
\end{tabular}

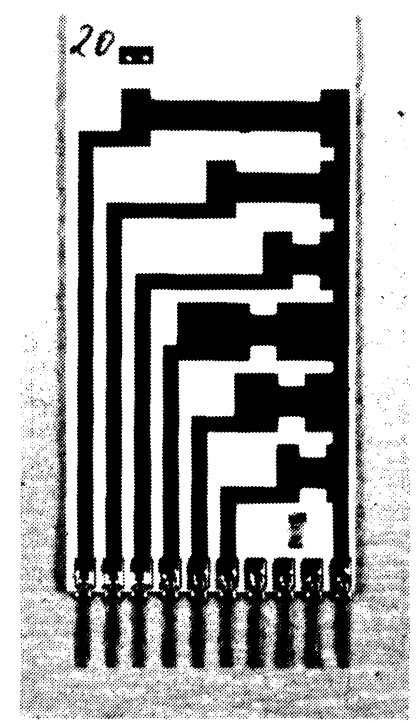

FIGURE 3 Ni thick film fired at peak temperature of $650^{\circ} \mathrm{C}$ (Substrate size 2" $\times 1$ ").

TABLE II

Test conditions

\begin{tabular}{lllll}
\hline Test no & $\begin{array}{l}\text { Ultrasonic } \\
\text { cleaning }\end{array}$ & Temperature & Humidity & Test time \\
\hline 1 & No & $25^{\circ} \mathrm{C}$ & - & $200 \mathrm{hrs}$ \\
2 & Yes & $40^{\circ} \mathrm{C}$ & $96 \%$ & $100 \mathrm{hrs}$ \\
3 & Yes & $70^{\circ} \mathrm{C}$ & - & $100 \mathrm{hrs}$ \\
\hline
\end{tabular}

with gradually decreasing peak temperatures and the same firing cycle. The conditions are summarised in Table I. Photographs of the resistive circuits prepared under firing conditions (1), (2) and (3) are shown in Figures 2A, B, C and under condition (4) in Figure 3. It can be seen that a smooth Nickel film was obtained only at a peak firing temperature of $650^{\circ} \mathrm{C}$ (firing conditions (4) - Table 1). A batch of 90 circuits was, therefore, produced under these conditions and the circuits completed by printing a resistive paste (series ESL 3100 ) and firing in a belt furnace firing cycle of $45 \mathrm{~min}$ with $10 \mathrm{~min}$ at a peak temperature of $580^{\circ} \mathrm{C}$.

The complete circuits were tested under different test conditions that are summarised in Table II. After these tests the adhesion of the Nickel thick film was 


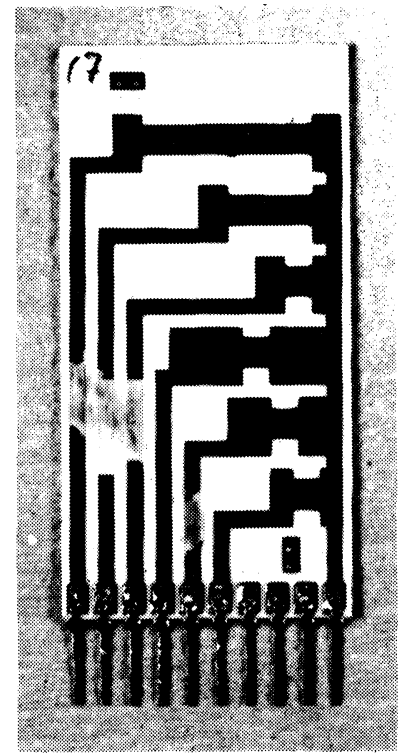

FIGURE $4 \mathrm{Ni}$ thick film fired at peak temperature of $650^{\circ} \mathrm{C}$ and tested under shelf conditions. (Substrate size 2" $\times 1 "$ ).

very low (see Figure 4). Furthermore, as a result of the high humidity test (test No. 2) the Nickel film was completely separated from the substrate. The adhesion of the resistive thick films, however, was always very high, independently of the test conditions.

\section{ELECTRICAL RESULTS}

Three batches of 20 circuits each were produced with $\mathrm{Ni}$ conductive film and with resistive films with sheet resistances of $10 \Omega / \mathrm{sq}, 1 \mathrm{~K} \Omega / \mathrm{sq}$ and $100 \mathrm{~K} \Omega / \mathrm{sq}(\mathrm{ESL} 3111$, 3113 and 3115 respectively). The nickel conductors were fired at the firing conditions shown under (4) in Table I, and the resistive films were fired in a belt furnace with a firing cycle of $45 \mathrm{~min}$ with $10 \mathrm{~min}$ at the peak temperature of $580^{\circ} \mathrm{C}$.

TABLE III

Results of resistance measurements

ESL $2554(\mathrm{Ni})$ after $48 \mathrm{~h}$ at $70^{\circ} \mathrm{C}$

ESL9633B

$(\mathrm{Ag} / \mathrm{Pd})$

after $100 \mathrm{hrs}$

at $70^{\circ} \mathrm{C}$

\begin{tabular}{lcrrrrrr}
\hline Resistor no & \multicolumn{1}{l}{ R1 } & \multicolumn{1}{c}{ R2 } & \multicolumn{1}{c}{ R3 } & \multicolumn{1}{c}{ R4 } & \multicolumn{1}{c}{ R5 } & \multicolumn{1}{l}{ R6 } & \\
\hline ESL M, \% & -0.22 & -0.55 & -0.414 & -0.159 & -0.947 & 0.383 & -0.105 \\
3111 S, \% & 3.235 & 2.529 & 11.296 & 0.574 & 3.233 & 6.526 & 0.084 \\
ESL M, \% & 0.798 & 0.336 & 0.590 & 0.150 & 0.625 & 0.387 & -0.082 \\
3113 S, \% & 2.298 & 1.369 & 3.560 & 1.519 & 3.401 & 2.679 & 0.017 \\
ESL M, \% & 6.525 & 5.027 & 4.261 & 4.343 & 4.797 & 4.554 & 0.190 \\
3115 S, \% & 1.920 & 1.335 & 0.738 & 0.994 & 1.226 & 0.771 & 0.046 \\
\hline
\end{tabular}


The resistances were measured immediately after production and also after 48 hours at $70^{\circ} \mathrm{C}$. The mean values, $\mathrm{M}$, and standard deviations, $\mathrm{S}$, of the resistance change, $\Delta R / R$, are given in Table III. The number of the resistors per substrate is six, as shown in Figure 1.

In order to obtain a comparison, a further batch of 20 circuits was prepared using $\mathrm{Ag} / \mathrm{Pd}$ conductors (ESL $9633 \mathrm{~B}$ ) and the last column of Table III gives the mean value and standard deviation of resistor changes for these. These were measured after a more extreme testing period in order to emphasize any change that may occur in the material.

The most important conclusion from these measurements is that the standard deviation of the resistance drift for the circuits with Nickel conductors are very high, sometimes higher than the mean value, and are much higher than the standard deviation of the resistance drift of circuits with $\mathrm{Ag} / \mathrm{Pd}$ conductive film. The large value of the standard deviation is a clear indication that the Nickel films are unstable not only under the conditions of the present test, but at all times. (c.f. the comments on Table II.)

\section{SURFACE ANALYSIS}

The Nickel films on the circuits that had completed the tests summarised in Table II, were investigated using Auger spectrometry. The results of the surface analysis are given in Table IV.

As the Nickel film was separated from the substrate after the high humidity test, it was possible to undertake surface analysis on the underside of the film. The results of the surface analysis on the underside of the Nickel film show traces of Nickel (3.8\%). This indicates that the glass phase on the film underside is not homogenous. Since the adhesion is due to the glass phase of the thick film, ${ }^{3}$ the presence of Nickel will imply a lowering of the adhesion.

On the surface of the Nickel film there are traces of Nickel (5.6\%). It is suggested that the stability of the Nickel thick film would be improved if the glass phase covers the metal phase on the film surface and in this manner protects the Nickel against the influence of the environment. This is important because of the chemical activity of Nickel. As a result, in the present situation, the influence, especially of humidity, will be considerable.

The other results from surface analysis (Test 1 and 3 - Table IV) are thought to be due to contamination and it is, therefore, not possible to discuss the actual film structure.

TABLE IV

Surface analysis of nickel films

\begin{tabular}{llllllllllll}
\hline $\begin{array}{l}\text { Test } \\
\text { no }\end{array}$ & $\begin{array}{l}\text { Investigated } \\
\text { position }\end{array}$ & $\begin{array}{l}\mathrm{O} \\
\mathbf{( \% )}\end{array}$ & $\begin{array}{l}\mathrm{B} \\
\mathbf{( \% )}\end{array}$ & $\begin{array}{l}\mathrm{Ni} \\
(\%)\end{array}$ & $\begin{array}{l}\mathrm{Al} \\
\mathbf{( \% )}\end{array}$ & $\begin{array}{l}\mathrm{C} \\
\mathbf{( \% )}\end{array}$ & $\begin{array}{l}\mathrm{Cl} \\
\mathbf{( \% )}\end{array}$ & $\begin{array}{l}\mathrm{K} \\
(\%)\end{array}$ & $\begin{array}{l}\mathrm{Pb} \\
(\%)\end{array}$ & $\begin{array}{l}\mathrm{S} \\
\mathbf{( \% )}\end{array}$ \\
\hline 1 & 70.5 & 5.1 & 0 & 4.2 & 8.3 & 5.9 & 0.3 & 5.2 & 0.4 \\
\hline $\begin{array}{l}\text { On the surface } \\
\text { of Ni film }\end{array}$ & 61.6 & 15.0 & 5.6 & 0 & 6.6 & 0 & 0.5 & 10.7 & 0 \\
& $\begin{array}{l}\text { On the surface } \\
\text { of Ni film }\end{array}$ & 60.7 & 35.4 & 3.8 & 0 & 0 & 0 & 0 & 0 & 0 \\
& $\begin{array}{l}\text { Underside of } \\
\begin{array}{l}\text { Ni film } \\
\text { On the surface } \\
\text { of Ni film }\end{array}\end{array}$ & 53.7 & 3.8 & 0 & 0 & 39.8 & 2.2 & 0 & 0 & 0.5 \\
\hline
\end{tabular}


TABLE V

Surface analysis of double fired Ni films

\begin{tabular}{llllllll}
\hline $\begin{array}{l}\text { Firing } \\
\text { conditions }\end{array}$ & $\begin{array}{l}\text { Investigated } \\
\text { position }\end{array}$ & $\begin{array}{l}\mathrm{O}, \\
(\%)\end{array}$ & $\begin{array}{l}\mathrm{C}, \\
(\%)\end{array}$ & $\begin{array}{l}\mathrm{B}, \\
(\%)\end{array}$ & $\begin{array}{l}\mathrm{Ni}, \\
(\%)\end{array}$ & $\begin{array}{l}\mathrm{Pb}, \\
(\%)\end{array}$ & $\begin{array}{l}\mathrm{Al}, \\
(\%)\end{array}$ \\
\hline $580^{\circ} \mathrm{C} / 580^{\circ} \mathrm{C}$ & $\begin{array}{l}\text { On the surface } \\
\text { of Ni film }\end{array}$ & 58.0 & 0 & 42.0 & 0 & 0 & 0 \\
& $\begin{array}{l}\text { In the bulk } \\
\text { of Ni film } \\
(6 \mu \mathrm{m} \text { from surface) }\end{array}$ & 3.9 & 9.8 & 7.3 & 78.9 & 0 & 0 \\
& $\begin{array}{l}\text { On the surface } \\
\text { of Ni film }\end{array}$ & 54.6 & 9.8 & 25.2 & 0 & 7.2 & 3.1 \\
& $\begin{array}{l}\text { In the bulk } \\
\text { of Ni film } \\
\left(650^{\circ} \mathrm{C} / 580^{\circ} \mathrm{C} \text { from surface) }\right.\end{array}$ & 2.8 & 6.6 & 8.6 & 82.1 & 0 & 0 \\
& & & & & & & \\
&
\end{tabular}

A $650^{\circ} \mathrm{C}$ peak temperature was high for the firing of $\mathrm{Ni}$ films and it was, therefore, of interest to compare the surface analysis results for films fired at $650^{\circ} \mathrm{C}$ with those fired at $580^{\circ} \mathrm{C}$.

All the circuits were also fired for a second time at $580^{\circ} \mathrm{C}$ peak temperature without printing the resistive film, since part of the contamination observed could be due to the firing products from the resistive films. To avoid the environmental contaminations the circuits were analysed immediately after the second firing. The results are given in Table $\mathrm{V}$.

It can be seen that the composition of the film surface (peak temperature $580^{\circ} \mathrm{C}$ ) is different from the film surface (peak temperature $650^{\circ} \mathrm{C}$ ) especially with regard to Boron. It is suggested that the Ni film fired at $580^{\circ} \mathrm{C}$ peak temperature is more stable than the film fired at $650^{\circ} \mathrm{C}$ and this could improve the adhesion effects during the film ageing. The structure in the film bulk is, however, almost the same, irrespective of firing, as the amount of the elements seen in surface analysis is approximately the same.

Since the structure of the alumina substrate was not known, surface analysis was undertaken on a clean substrate using an x-ray photoelectron spectrometer. The results are given in Table VI. The elements that are concentrated within the first $20 \AA$ of the surface will show an increased signal for the low angle $\left(60^{\circ}\right.$ to normal) beam. The presence of Silicon can be noted and this could also be a possible cause of the low adhesion, as this could indicate an alumina surface initially contaminated with silicones.

\section{DISCUSSION}

The experimental results presented lead to the conclusion that the maximum firing

TABLE VI

Surface analysis of $96 \% \mathrm{Al}_{2} \mathrm{O}_{3}$ substrate

\begin{tabular}{|c|c|c|c|c|c|c|c|c|}
\hline $\begin{array}{l}\text { Angle of } \\
\text { electron } \\
\text { beam to } \\
\text { normal }\end{array}$ & $\begin{array}{l}\text { Depth } \\
(\AA)\end{array}$ & $\begin{array}{l}\mathrm{Al}, \\
(\%)\end{array}$ & $\begin{array}{l}\mathrm{Si}, \\
(\%)\end{array}$ & $\begin{array}{l}\mathrm{C}, \\
(\%)\end{array}$ & $\begin{array}{l}\mathrm{Mg}, \\
(\%)\end{array}$ & $\begin{array}{l}\mathrm{Ca}, \\
(\%)\end{array}$ & $\begin{array}{l}\mathrm{O}, \\
(\%)\end{array}$ & $\begin{array}{l}\mathrm{Na} \\
(\%)\end{array}$ \\
\hline $0^{\circ}$ & 30 & 33.3 & 4.3 & 5.6 & 1.4 & 0.3 & 54.0 & 1.1 \\
\hline $60^{\circ}$ & 30 & 32.36 & 6.0 & 7.0 & 1.1 & 0.2 & 52.2 & 0.8 \\
\hline
\end{tabular}


peak temperature of Nickel paste (ESL 2554) for a belt furnace firing (45 min cycle with $10 \mathrm{~min}$ at peak temperature) is $580^{\circ} \mathrm{C}$. The photographs, Figures $2 \mathrm{~A}, \mathrm{~B}$ and $\mathrm{C}$, confirm that peak temperatures higher than $650^{\circ} \mathrm{C}$ are not appropriate for $\mathrm{Ni}$ air fireable paste. The results of Table III and Figure 4 also show that a peak temperature of $650^{\circ} \mathrm{C}$ is not satisfactory for firing the Ni paste - ESL 2554. Investigations are continuing on the properties of Nickel thick film fired at $580^{\circ} \mathrm{C}$ peak temperature.

The results presented in this paper show that the application of air fireable Nickel paste ESL 2554 is restricted by the low peak firing temperature. The dependence of the resistivity on the peak firing temperature of Nickel thick film shown by Stein et $\mathrm{al}^{2}$ cannot be obtained unless special firing conditions are used.

\section{CONCLUSION}

The following conclusions are made:-

a) Nickel thick film conductors are not homogeneous in Nickel content - there is little nickel at the film surfaces.

b) Even a little Nickel at the film - substrate interface, lowers the adhesion obtained.

c) The small amount of Nickel at the top surface of the film produces a sensitivity of the film to humidity.

d) Adhesion of the film to the substrate is poor under high humidity conditions.

e) $650^{\circ} \mathrm{C}$ is too high a firing temperature to give satisfactory stable nickel thick film conductors; $580^{\circ} \mathrm{C}$ is suggested as the maximum peak firing temperature.

\section{ACKNOWLEDGEMENTS}

The authors are grateful to Dr. J.M. Walls and his colleagues for the surface analysis results. One of us (R.B.P.) is grateful to the Bulgarian Ministry of Education and the British Council for travel and study facilities.

\section{REFERENCES}

1. Bulletin 3281, Conductive Coatings 2557, 2590, 2560, Electro-Science Laboratories Inc.

2. S.J. Stein, C. Huang and L. Cang, "Possibilities for Air Base Metal Conductors",Electrocomponent Science \& Technology, 8, pp 159-166, (1981).

3. D.W. Hammer \& J.V. Biggers. Thick Film Hybrid Microcircuit Technology. Wiley Interscience. 1972. 

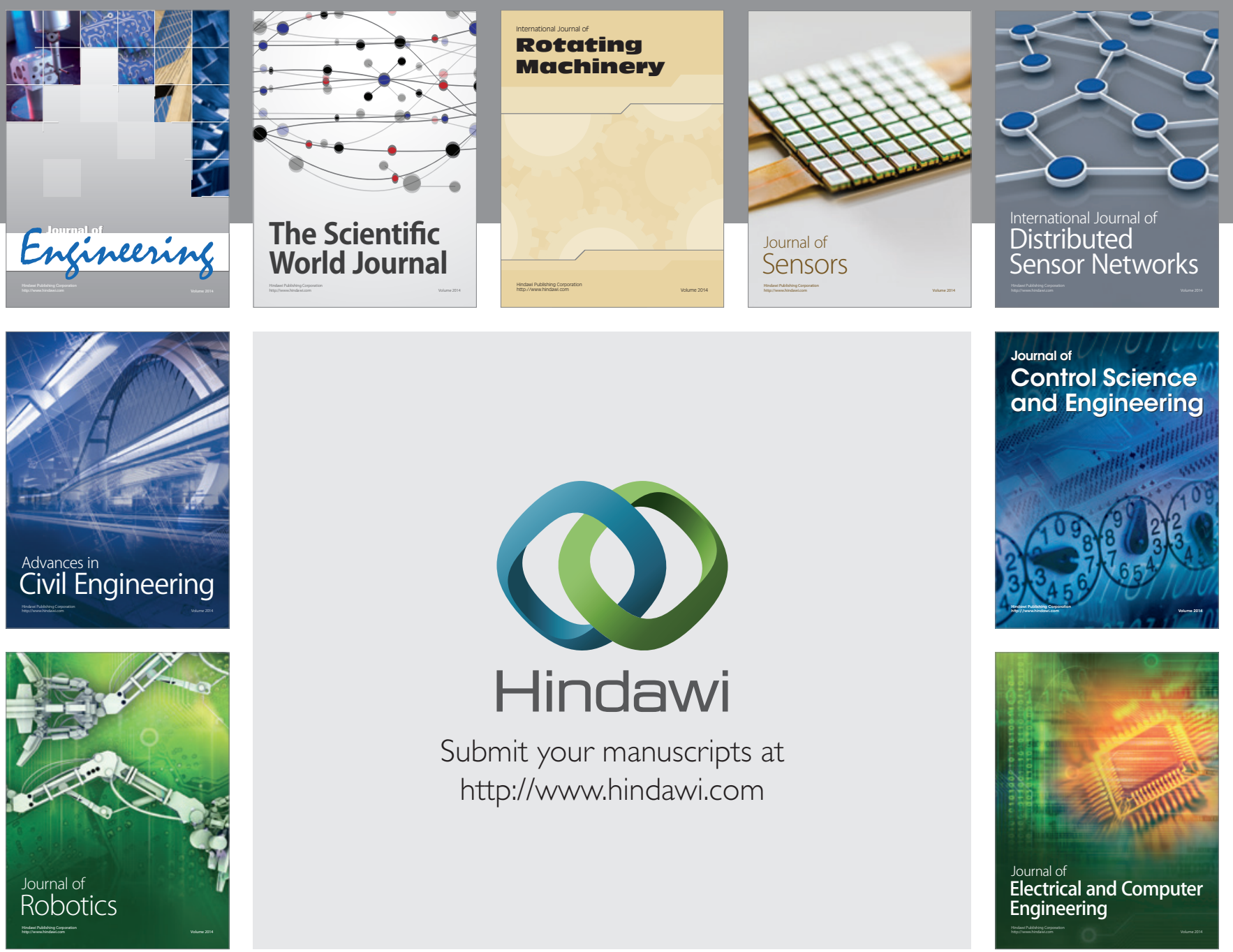

Submit your manuscripts at

http://www.hindawi.com
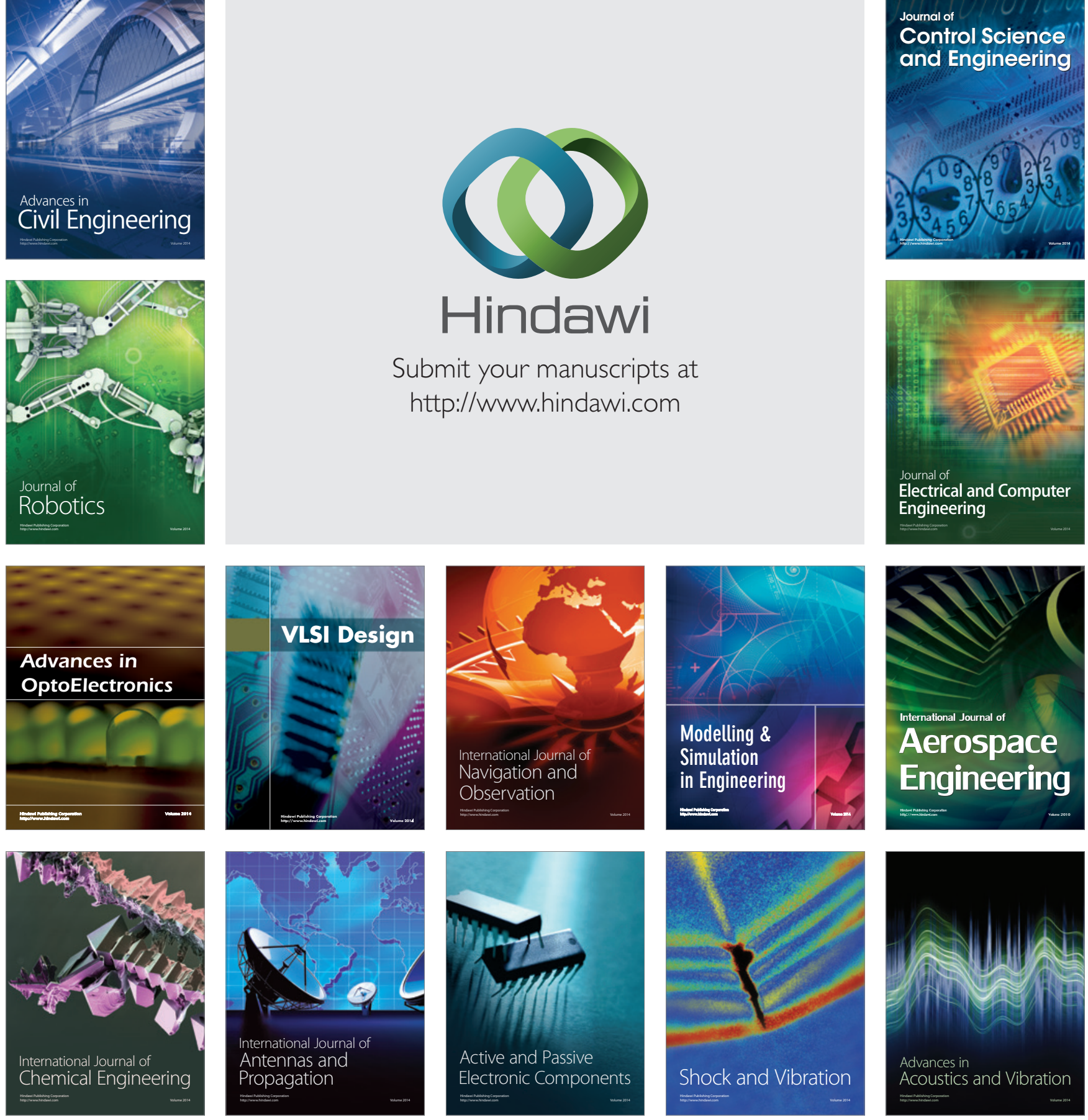